\title{
Description of the soil and root biomass of two subtropical mangroves in Antonina and Guaratuba Bay, Paraná State, Brazil
}

\author{
Ana Paula Lang Martins Madi ${ }^{1,3}$, Maria Regina Torres Boeger ${ }^{1}$ and Carlos Bruno Reissmann²
}

Received: 23.11.2016; accepted: 2.05.2017

\begin{abstract}
Description of the soil and root biomass of two subtropical mangroves in Antonina and Guaratuba Bay, Paraná State, Brazil). The soil of the mangroves influences the root anchorage and the nutrition processes of the plant community. This study evaluated the relationships among edaphic conditions, volume and biomass of roots, and tree structure of two mangroves in Paraná State. Five soil cores of $50 \mathrm{~cm}$ depth were collected from each mangrove for physicochemical analysis. Organosoil thiomorphic salic sodic predominated in Antonina Bay, while in Guaratuba Bay were observed the Gleysoil thiomorphic salic sodic and the Organosoil thiomorphic salic sodic. Fifteen root samples were collected from each mangrove area for root volume and dry mass analysis'?'. The higher values of root mass were found in Guaratuba Bay. The chemical analysis of the soil showed no correlation between biomass and root volume. The high coefficients of variation attested the high heterogeneity in the root distribution in both areas. However, in the Guaratuba Bay, root mass and volume are higher due to the textural composition of the soil and higher tree density.
\end{abstract}

Keywords: gleisoil, organosoil, root dry mass, root volume

RESUMO - (Descrição do solo e biomassa radicular de dois manguezais subtropicais nas Baías de Antonina e Guaratuba, PR, Brasil). O solo do manguezal influencia a fixação e o processo nutricional da comunidade das plantas. Este estudo avaliou as relações entre as condições edáficas, volume e biomassa radicular e a estrutura de dois manguezais no estado do Paraná. Foram coletadas quinze amostras de solo até a profundidade de $50 \mathrm{~cm}$ em cada um dos manguezais. Na Baía de Antonina predominou o Organosolo Tiomórfico sálico sódico, enquanto na Baía de Guaratuba foram encontrados Gleisolo Tiomórfico sálico sódico e Organosolo Tiomórfico sálico sódico. Foram coletadas quinze amostras de raízes para determinar o volume e massa seca, em cada manguezal. Valores mais altos de biomassa radicular foram encontrados na Baía de Guaratuba. A análise química do solo não apresentou correlação com a biomassa e o volume radicular. Os altos coeficientes de variação atestam a elevada heterogeneidade na distribuição das raízes em ambas as áreas. No entanto, na Baía de Guaratuba foi constatada uma biomassa e volume maior de raízes devido a composição textural do solo e a maior densidade arbórea nesta área.

Palavras-chave: gleissolo, massa radicial, organossolo, volume de raízes

\section{Introduction}

Mangroves are renowned for their biomass production, being one of the most productive ecosystems in the world (Tomlinson 1986). They are characterized by periodic inundations with seawater, variation in salinity, low levels of oxygen and muddy soils, and are important transformers of nutrients in organic matter and food (Menezes 2000).

Mangrove ecological characteristics are determined by geomorphology and landscape processes, while mangrove architecture is the result of the interaction between the species that live there and the environmental forces that influence the system (Sessegolo 1997). The development of mangroves is associated with climatic, hydrologic and geomorphologic conditions, and tropical temperatures, tide amplitudes, presence of fresh water, and protected coastal areas are the basic prerequisites for the establishment and maintenance of mangrove ecosystems (Ferreira 2002).

Mangrove soils make a large contribution to the aquatic ecosystem because they are home to a great

1. Universidade Federal do Paraná, Programa de Pós-graduação em Ecologia e Conservação, Centro Politécnico, Caixa postal 19031, 81531-980 Curitiba, PR, Brasil

2. Universidade Federal do Paraná, Departamento de Solos e Engenharia da Agricultura, Rua dos Funcionários, 1.540, 80035-020 Curitiba, PR, Brasil

3. Corresponding author: langmartins@hotmail.com 
diversity of organisms. These soils are important for particle transport, the accumulation of nutrients and organic compounds and as a source of food for many organisms from varied trophic levels (Silverio 2003). Mangrove soils are classified as halomorphics, which are developed from sea- and freshwater sediments and have high organic matter content. These soils include Gley and Organosoils (Embrapa 1978) and are predominately comprised of fine particles, such as silt and clay, high levels of organic matter and soluble salts due the presence of seawater (Cintron \& Schaffer-Novelli 1983). The structural and chemical compositions of the soil are important factors in determining the density and abundance of mangrove tree species (Madi et al. 2016).

Four genera of tree species are present in Brazilian mangroves: Rhizophora (Rhizophoraceae), Avicennia (Avicenniaceae), Laguncularia and Conocarpus (Combretaceae). These tree species are adapted to colonize and develop in unconsolidated soil and perform the main function of nutrient cycling since they are the primary source of organic matter (Amarasinghe \& Balasubramannian 1992).

Generally, mangrove ecosystems have a large stock of roots with high root biomass, which provides a large amount of organic matter due to the slow decomposition in the anoxic conditions and periodic flooding of the soil (Komiyama et al. 2008). Among the root systems of mangroves, fine roots (roots $<2 \mathrm{~mm}$ of diameter; Rosado et al. 2011) play an important function in nutrient cycling because they make a great contribution to the dynamics of belowground phytomass. Fine roots are directly related to soil respiration, mycorrhiza activities and water and nutrient absorption, especially phosphorous (Kummerow et al. 1990).

Investigations into total root biomass in mangroves estimate that they comprise 11.7 to $306.2 \mathrm{t} \mathrm{ha}^{-1}$, while fine roots comprise 6.1 to $9.1 \mathrm{tha}^{-1}$. The ratio of aerial parts to root parts in several mangroves was found to vary from 1.1 to 4.4 , indicating that a larger amount of biomass is allocated to below ground (Komiyama et al. 2008).

Previous studies of mangrove structure in two areas on the coast of the state of Parana, Brazil, found differences in tree composition (Madi et al. 2016). The density of Avicennia schaueriana and the density and dominance of Laguncularia racemosa and Rhizophora mangle were the main features that distinguished the tree structure of these two mangroves. Furthermore, these differences were found related to the higher salinity of Guaratuba Bay and the higher organic matter content of Antonina Bay (Madi et al. 2016). Based on this information, this study evaluated the relationship between edaphic conditions and root biomass in the both mangrove areas to contribute with better understanding of relationships between soil and vegetation.

\section{Material and methods}

This study was performed in two mangrove areas on the coast of the State of Paraná: one located in the estuary of the Rio Nhundiaquara in Antonina Bay; and the other located on the estuary of the Rio Pinheiros in Guaratuba Bay (figure 1). The geographic coordinates and climatic features of the two study areas are presented in table 1 . Table 2 shows the geographic coordinates of the sample points.

Soil analysis. Fifteen soil samples were collected to $50 \mathrm{~cm}$ deep with a "Napoleon"-type auger. Each soil sample was divided into five sub-samples based on depth ( 0 to 10,10 to 20,20 to 30,30 to 40 and 40 to $50 \mathrm{~cm}$ ), air dried and then sifted to obtain the air-dried soil fraction TFSA $(\varphi<2 \mathrm{~mm})$. The fractions were subsequently analyzed for $\mathrm{pH} \mathrm{CaCl}_{2}$; pH SMP; phosphorous $(\mathrm{P})$, calcium $(\mathrm{Ca})$, magnesium $(\mathrm{Mg})$, potassium $(\mathrm{K})$ and Sodium $(\mathrm{Na})$; extractable aluminum and sulfuric acid $\left(\mathrm{H}_{2} \mathrm{SO}_{4} 1: 1\right)$, according to "Manual de Análise do Solo" (EMBRAPA, 1997). Due to the soil prossessing method, the very high organic matter content had to be eliminated and in this sense, physical analysis was preceded by peroxide 30 vol. treatment. ICP-OES (inductively coupled

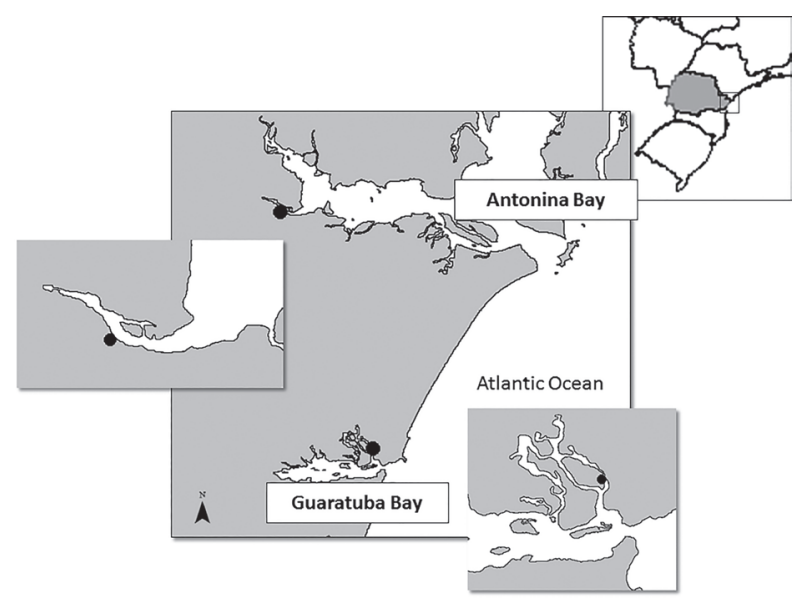

Figura 1. Study areas in the mangrove of the Nhundiaquara River estuary (Antonina, Paraná State, Brazil) and in the mangrove of the Pinheiros River estuary (Guaratuba, Paraná State, Brazil). 
Table1. Geographic coordinates and abiotic characteristics of the study areas at Rio Nhundiaquara (Antonina Bay) and Rio Pinheiros (Guaratuba Bay), Paraná State, Brazil. IWS: interstitial water salinity, RP: redox potential.

\begin{tabular}{lcc}
\hline & Antonina Bay & Guaratuba Bay \\
\hline Geographic coordinates $^{* *}$ & $25^{\circ} 29^{\prime} \mathrm{S} 48^{\circ} 42^{\prime} \mathrm{W}$ & $25^{\circ} 50^{\prime} \mathrm{S} 48^{\circ} 34^{\prime} \mathrm{W}$ \\
Temperature $\left.^{\circ} \mathrm{C}\right)^{*}$ & 20.5 & 20.8 \\
Climate $^{*}$ & $\mathrm{Cfa}$ & $\mathrm{Cfa}$ \\
${\text { Annual precipitation }(\mathrm{mm})^{*}}^{*}$ & 2733 & 3183 \\
IWS $(\%))^{* *}$ & 18.6 & 27.6 \\
$\mathrm{RP}(\mathrm{mV})^{* *}$ & -339 & -318.6 \\
\hline
\end{tabular}

*Data from SIMEPAR for 2010. **Boeger et al. (2011).

Table 2. Geographic coordinates of the sampling points at Rio Nhundiaquara (Antonina Bay) and Rio Pinheiros (Guaratuba Bay), Paraná State, Brazil.

\begin{tabular}{|c|c|c|}
\hline & Antonina Bay & Guaratuba Bay \\
\hline Samples 1-5 & $25^{\circ} 29^{\prime} 50.97^{\prime \prime S}$ e $48^{\circ} 41^{\prime} 29.46^{\prime \prime} \mathrm{W}$ & $25^{\circ} 50^{\prime} 00.35^{\prime \prime S}$ e $48^{\circ} 34^{\prime} 52.52^{\prime \prime} \mathrm{W}$ \\
\hline Samples 6-10 & $25^{\circ} 29^{\prime} 57.20^{\prime \prime S}$ e $48^{\circ} 42^{\prime} 40.44^{\prime \prime} \mathrm{W}$ & $25^{\circ} 49^{\prime} 43.47^{\prime \prime S}$ e $48^{\circ} 34^{\prime} 52.08^{\prime \prime} \mathrm{W}$ \\
\hline Samples 11-15 & $25^{\circ} 29^{\prime} 51.91 " \mathrm{~S}$ e $48^{\circ} 42^{\prime} 43.67^{\prime \prime} \mathrm{W}$ & $25^{\circ} 49^{\prime} 43.37^{\prime \prime S}$ e $48^{\circ} 34^{\prime} 57.36^{\prime \prime} \mathrm{W}$ \\
\hline
\end{tabular}

plasma-optical emission spectrometry) was employed for detecting $\mathrm{Al}$, trace elements and micronutrients according to EPA 3051a.

The sample digestion procedure followed the method described in EPA 3051a (Microwave 108 Assisted Acid Digestion of Sediments, Sludges, Soils, and Oils). Carbon $(\mathrm{C})$ and Nitrogen $(\mathrm{N})$ contents were determined by combustion using a VARIO-ELIII Elementar®109 model analyzer. Organic Matter was obtained multiplying $C$ content by 1,724 factor (EMBRAPA, 1997).

Root analysis - Root samples were collected at fifteen points, by the stems, and separated from each other by at least $10 \mathrm{~m}$, in each bay, using a "Napolean"-type auger. Each root sample was divided in three sub-samples, at three depths: 0-10, 10-20 and 20-30 cm, for a total of 90 samples. No roots were found deeper then $30 \mathrm{~cm}$. Samples were stored in plastic bags until analysis. For analysis, samples were washed in running water to eliminate excess soil. Root volume was estimated from the volume of water displaced in a graduated beaker with the addition of the sample. The samples were then sifted in a fine net to remove water, dried in a stove at $60{ }^{\circ} \mathrm{C}$, and measured for dry mass using an analytical balance with $0.0001 \mathrm{~g}$ of accuracy. Means and standard deviations were calculated for all quantitative variables.

\section{Results and Discussion}

The soil types of the studied areas belonged to two groups - Tiomorphic Sapric Saline/Sodic Organosols (Organossolo Tiomórfico Sálico sódico) predominated in Antonina Bay and Tiomorphic Sapric, Saline/ Sodic Gley (Gleissolo Tiomórfico Sálico sódico) soils and Tiomorphic Sapric Saline/Sodic Organosols (Organossolo Tiomórfico Sálico sódico) in Guaratuba Bay (Embrapa 1999). A soil is considered an Organosol when the carbon content is equal to or higher than $80 \mathrm{~g} \mathrm{~kg}^{-1}$, as determined from evaluating the fraction of air dried soil passed through a $2 \mathrm{~mm}$ sieve (TFSA), as were the soils found in this study (table 3). Presently, Tiomorphic soils are grouped into the soil classes of Gley soils and Organosoils that possess a sulfuric horizon formed by oxidation of sulfidric materials (Embrapa 1999).

Due to high Na saturation, the soil of both Antonina and Guaratuba bays, with $49 \%$ and $60.5 \%$ $\mathrm{Na}$, respectively, can be classified as sodic. It is important to point out that values of $\mathrm{Na}$ greater than $15 \%$ classify the soil as saline (Emater 1998). The $\mathrm{Na}$ values were estimated for the two first layers of the soil, where the CTC was lower (table 4). Soil conductivity values above $7 \mathrm{dS} \mathrm{m}^{-1}$ at $25^{\circ} \mathrm{C}$, as in the studied soils, are classified as salic. It is also important to observe these aspects, once $\mathrm{Na}$ alone in these soils 


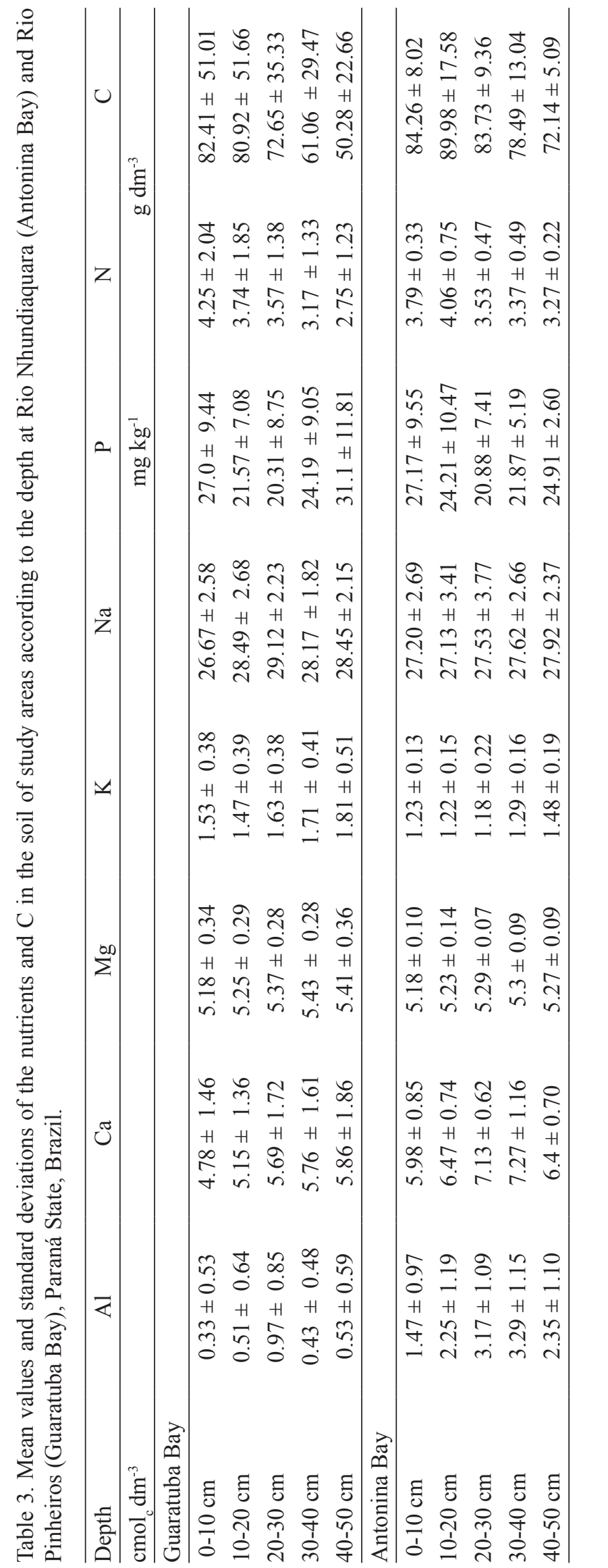

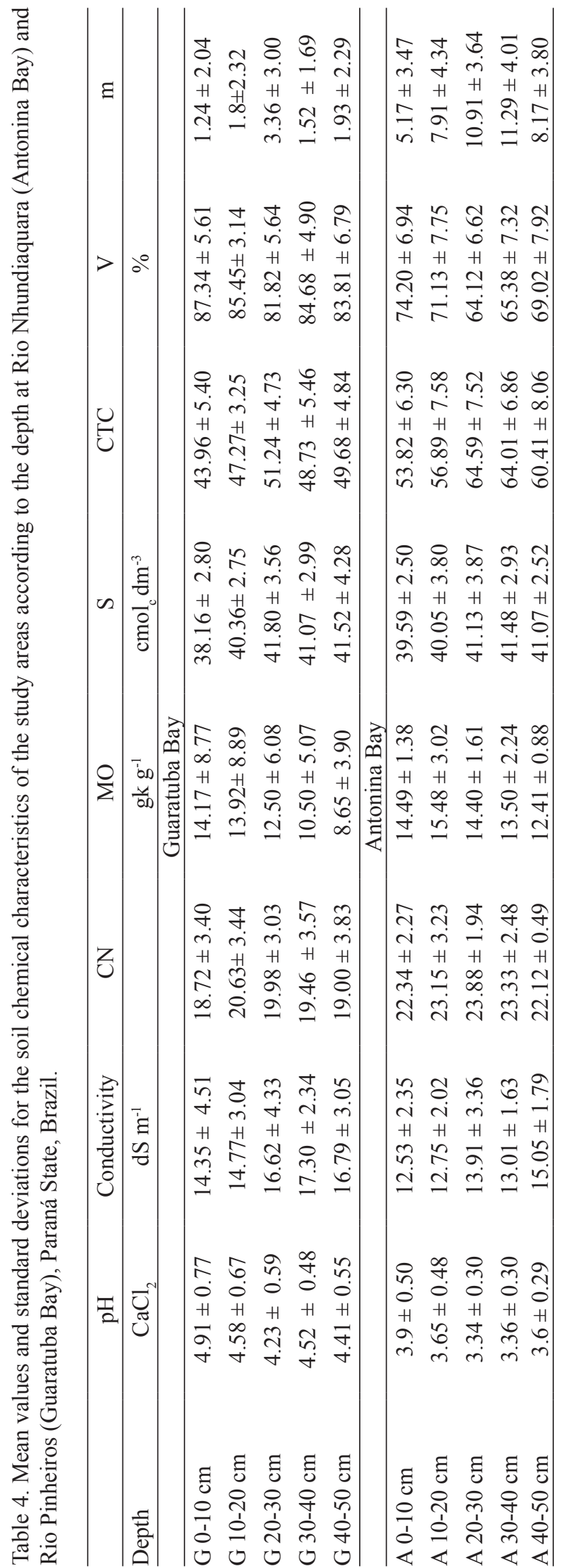


occupies 50 to $60 \%$ of the charges of the exchangeable sites. The sapric classification of the soil in both bays was related to organic matter content in advanced stage of decomposition, with low content of fibers, high density of roots and low water retention capacity (Embrapa 2006).

In Antonina Bay, franco-clayey and silty clay classes were predominant, while in Guaratuba Bay, franco-clayey-silty, silty clay and sandy loam classes predominated (table 5). However, it is not possible to specify the exact origin of these materials due the different contributions of three geological formations: "Serra do Mar", "Primeiro Planalto" and coastal plain (Angulo 2004). Antonina Bay exhibited higher values of glay in relation to Guaratuba Bay, while silt and sand fractions were higher in Guaratuba Bay (table 5). These results differ from those of Prada-Gamero et al. (2004) and Rossi \& Mattos (2002), who found mainly sandy loam texture in their study mangroves, probably due to the origin of deposited material.

Soil $\mathrm{pH}$, determined by $\mathrm{CaCl}_{2}$ solution, after being air dried, was very low (i.e., acidic) in both bays (Emater 1998), with Antonina Bay being classified as having "very high acidity" and Guaratuba Bay as having "high acidity". These results are contrary to the very high values for basic exchange cations (table 4), but do not reflect the physico-chemical conditions in loco, because the higher acidity can be attributed to $S$ oxidation during the soil drying process (Rossi \& Mattos 2002). Furthermore, there are other considerations to take into account regarding the low $\mathrm{pH}$ values of dried mangrove soil, such as surface sulfide oxidation (Bernini and Rezende 2010), and the presence of fulvic acids (Araújo et al. 2010).

The exchangeable bases $(\mathrm{Ca}, \mathrm{Mg}, \mathrm{K}$ and $\mathrm{Na}$ ) were classified as "very very high" (table 3 ), (SBCS 2004), as was soil CTC. In Antonina Bay, CTC ranged from 53.8 to $64.6 \mathrm{cmol}_{\mathrm{c}} \mathrm{dm}^{-3}$, while in Guaratuba Bay, in ranged from 44.0 to $51.2 \mathrm{cmol}_{c} \mathrm{dm}^{-3}$, depending on depth (table 4). Soil fertility, represented by base saturation $(\mathrm{V} \%$, table 4$)$ of the $0-10 \mathrm{~cm}$ layer, was highly correlated with $\mathrm{pH}$, with $\mathrm{r}=0.87$ and $\mathrm{r}=0.72$ $(p<0.05)$, in Antonina Bay and Guaratuba Bay, respectively (table 4).

Carbon (C) and Organic Matter (OM) content were higher in the superficial layers in both study areas (tables 3 and 4). The mean values of $\mathrm{C}$ and $\mathrm{OM}$ are considered "very high" (>20 $\mathrm{g} \mathrm{dm}^{-3}$; SBCS 2004), especially for agricultural soils, but very common for mangrove soils due to organic carbon levels close to $200 \mathrm{~g} \mathrm{dm}^{-3}$ (Prada-Gamero et al. 2004). There are strong evidences that mangroves promote high rates of O.M., accumulation and incorporation (Barreto et al., 2016), preserving high levels of carbon in the soil. The contrary occurs as soils derived from natural environments e.g., like forests, that show a strong decline in the original O.M. content when transformed in pastures, i.e., human intervention diminish organic matter accumulation (La Scala Jr. et al. 2012).

Nitrogen (N) content can be assumed to be "high", considering the high OM values, which is the source of $\mathrm{N}$ (table 4). However, total $\mathrm{N}$ can not be considered fully available, since it has to be mineralized to

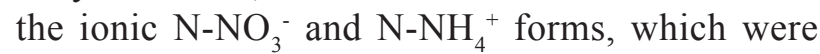
not investigated. Although the $\mathrm{C}: \mathrm{N}$ ratio is higher than 20:1, which is above the ratio for satisfactory mineralization, as observed in fertile well aerated soils (Luchese et al. 2001).

Phosphorus (P) content may also be linked to $\mathrm{OM}$, because it was higher in the superficial layers of the soil in both bays (table 4). The presence of up to $50 \%$ of P-organic in forest soils may be related to the close relationship of this element with OM (Novais \& Smyth 1999). However, it is not possible to say that this proportion remains in mangrove soils.

The higher values of $\mathrm{P}$ in the superficial layers, and the fact that this element is associated with organic-P, are also well supported by the findings of Prasad \& Ramanathan (2009), who reported $500 \mu \mathrm{g} \mathrm{g}^{-1}$ of organic-P in mangrove soils, which exceeded the values found in the present study by 18.5 times. It is important to point out that $\mathrm{P}$, represented by $\mathrm{P}-$ Mehlich, did not discriminate organic $\mathrm{P}$ from mineral $\mathrm{P}$, the latter of which is related more to extractable $\mathrm{P}$, and to $\mathrm{Fe}, \mathrm{Al}$ and adsorbed by clay (Marques 2006). Phosphorous is an immobile element in the soil, forming complexes of low solubility (Novais et al. 2007). However, organic-P- and nutrient cycling are a source of $\mathrm{P}$ for mangrove tree species since this type of $\mathrm{P}$ is not subject to immediate unavailability due to precipitation or fixation.

The distribution of $\mathrm{P}$ among different layers of the soil in both bays, indicated a reduction of this element below the $20-30 \mathrm{~cm}$ layer. The higher values for deeper layers at Guaratuba Bay are probably due to the original deposition of the material (Angulo 2004, Araújo et al. 2010).

Guaratuba Bay had higher values for volume and dry mass of fine and medium-sized roots at all depths (table 6). In both bays, however, both root volume and dry mass varied with depth, with lower values occurring at 20 to $30 \mathrm{~cm}$ deep. However, the high values of the variation coefficient (table 6) indicate 
Table 5. Mean values and standard deviations for the levels of sand, silt and clay in the study areas according to the depth at Rio Nhundiaquara (Antonina Bay) and Rio Pinheiros (Guaratuba Bay), Paraná State, Brazil.

\begin{tabular}{lccc}
\hline Depth & Sand & Silt & Clay \\
\hline \multicolumn{4}{c}{$\%$} \\
\hline $0-10 \mathrm{~cm}$ & Antonina Bay \\
$10-20 \mathrm{~cm}$ & $28.7 \pm 16.1$ & $40.7 \pm 3.9$ & $31.0 \pm 8.0$ \\
$20-30 \mathrm{~cm}$ & $17.3 \pm 7.8$ & $44.3 \pm 2.4$ & $39.0 \pm 5.1$ \\
$30-40 \mathrm{~cm}$ & $20.0 \pm 7.5$ & $44.3 \pm 3.8$ & $36.0 \pm 4.9$ \\
$40-50 \mathrm{~cm}$ & $17.7 \pm 6.8$ & $42.7 \pm 4.9$ & $40.3 \pm 4.5$ \\
\hline & $22.7 \pm 20.2$ & $37.3 \pm 10.8$ & $40.0 \pm 9.4$ \\
\hline $0-10 \mathrm{~cm}$ & \multicolumn{3}{c}{ Guaratuba Bay } \\
$10-20 \mathrm{~cm}$ & $30.0 \pm 29.1$ & $40.0 \pm 16.1$ & $30.0 \pm 13.5$ \\
$20-30 \mathrm{~cm}$ & $38.0 \pm 27.6$ & $38.7 \pm 16.3$ & $23.3 \pm 11.3$ \\
$30-40 \mathrm{~cm}$ & $12.3 \pm 3.7$ & $48.0 \pm 2.9$ & $40.3 \pm 2.0$ \\
$40-50 \mathrm{~cm}$ & $7.0 \pm 1.6$ & $52.7 \pm 3.4$ & $41.0 \pm 1.6$ \\
\hline
\end{tabular}

Table 6. Mean values and standard deviations of the volume and dry mass of roots in the study areas at different depths at Rio Nhundiaquara (Antonina Bay) and Rio Pinheiros (Guaratuba Bay), Paraná State, Brazil. CV: coefficient of variation.

\begin{tabular}{lccccc}
\hline Area & Depth & $\begin{array}{c}\text { Volume } \\
\left(\mathrm{mL} \mathrm{L}^{-1}\right)\end{array}$ & $\begin{array}{c}\mathrm{CV} \\
(\%)\end{array}$ & $\begin{array}{c}\text { Dry mass } \\
\left(\mathrm{g} \mathrm{L}^{-1}\right)\end{array}$ & $\begin{array}{c}\mathrm{CV} \\
(\%)\end{array}$ \\
\hline Antonina Bay & $0-10$ & $326.7 \pm 91.5$ & 28 & $32.0 \pm 16.8$ & 30.9 \\
& $10-20$ & $335.4 \pm 168.2$ & 50.1 & $35.2 \pm 10.9$ & 52.5 \\
& $20-30$ & $275.0 \pm 120.7$ & 43.9 & $31.3 \pm 16.1$ & 51.4 \\
\hline Guaratuba Bay & $0-10$ & $521.6 \pm 181.5$ & 34.8 & $60.0 \pm 25.1$ & 41.8 \\
& $10-20$ & $595.4 \pm 239.9$ & 40.3 & $69.8 \pm 30.3$ & 43.4 \\
& $20-30$ & $482.5 \pm 119.5$ & 24.8 & $53.3 \pm 13.9$ & 26.1 \\
\hline
\end{tabular}

a heterogeneous distribution of roots in the studied areas.

The higher values of root biomass found in Guaratuba Bay are probably related to several factors. The textural composition of the soil in this area has a greater proportion of sand, which facilitates the deeper development of roots and, consequently, an increase in volume (Fitter 1987). The volume of roots in mangrove soils is an important characteristic because it contributes organic matter annually (McKee 2011), but this addition is dependent on the decomposition rate of these roots (Huxham et al. 2010). Some studies demonstrated that root decomposition could vary among species due to intrinsic features of each species and their chemical composition (Huxham et al. 2011).

Another factor that can influence variation in volume and dry mass of roots is the basal area and density of individual trees. Previous studies have shown that these parameters varied between the two study areas, with Antonina Bay having a higher density of individuals than Guaratuba Bay, but with heterogeneous distribution patterns between sampled plots. However, in Guaratuba Bay, several individuals exhibited higher diameters (Madi et al. 2016), which interfere in the total basal area. Variation in the structure of mangroves, based on diametrical distribution, can also affect local root biomass, as observed in this study. In an earlier investigation, the variation in structure was attributed to differences in the salinity and organic matter content of the soil (Madi et al. 2016). It is important to address that the locations of the bays related to open sea is also an important factor that influences the mangrove dynamics, especially tides and, consequently, the vegetation structure.

Lastly, it should be noted that the root volume observed in the present study considered only fine and medium-sized roots. However, roots with greater 
diameters were also found and occupy large volumes within mangrove soil, although they do not actively contribute to the function of absorption due to their high degree of lignification (Reef et al. 2010).

In conclusion, the soil data showed no relation between biomass and root volume. The variation coefficients attested the high heterogeneity of root distribution in both areas. However, in Guaratuba bay, the mass and root volumes are probably greater due to the textural soil composition and the higher density of individuals. These data also showed there is a high complexity of mangrove root system with the physical environment. However, the root complex is still very poor understood on Brazilian mangroves and it needs further studies to better understanding this important ecosystem.

\section{Acknowledgements}

The authors are grateful to the Coordenação de Aperfeiçoamento de Pessoal de Nível Superior (CAPES) for scholarship to the first author, to CNPq, Fundação Araucaria and Petrobras SA for financial support, and to the productivity fellowship to the second author (process $n^{\circ} 301971 / 2013-7$ ).

\section{Literature cited}

Amarasinghe, M.D. \& Balasubramanniam, S. 1992. Structural properties of two types of mangrove stands on the northern western coast of Sri Lanka. Hydrobiologia 247:17-27.

Angulo, R.J. 2004. Cenozoic map of the state of Paraná coastal zone. Boletim Paranaense de Geociências 55: 25-42.

Araujo, Q.R., Krause, R.L.O., Santana, S.O., Araujo, T.G., Mendonça, J.R. \& Trindade, A.V. 2010. Caracterização de Solo de Manguezal na Bacia Hidrográfica do Rio Graciosa, Bahia, Brasil [Internet]. Long Beach, Califórnia: Encontro Internacional Anual das Sociedades Americanas de Agronomia, Fitotecnica e Ciência do Solo. Available in http://www.ateffaba.org. $\mathrm{br} / \mathrm{p}=6930$ (access in 04-X-2015).

Barreto, M.B., Mónaco, S.L., Díaz, R., BarretoPittol, E., Lopes, L. \& Peralba, M.C.R. 2016. Soil organic carbono f mangroves forests (Rhizophoraand Avicennia) of the Venezuelan Caribbean coast. OrganicGeochemistry 100: 51-61.

Bernini, E. \& Rezende, C.E. 2010. Concentração de nutrientes em folhas e sedimentos em um manguezal do norte do estado do Rio de Janeiro. Revista Gestão Costeira Integrada 2:1-10.

Boeger, M.R.T. 2011. Diagnóstico ictiofaunístico em ambientes afetados por vazamento de óleo na Serra do Mar, no estado do Paraná. FUNPAR, Curitiba.
Citrón, G. \& Schaeffer-Novelli, Y. 1983. Introdución a la ecologia del manglar. Rostlac, San Juan.

Embrapa (Empresa Brasileira de Pesquisa Agropecuária). 1978. Levantamento de reconhecimento dos solos do estado do Espírito Santo. Centro Nacional de Pesquisa de Solos, Rio de Janeiro.

Embrapa (Empresa Brasileira de Pesquisa Agropecuária). 1997. Manual de Métodos de Análises de Solo. Centro Nacional de Pesquisas de Solo, Embrapa-CNPS, Rio de Janeiro.

Embrapa (Empresa Brasileira de Pesquisa Agropecuária). 1999. Sistema brasileiro de classificação de solos. Centro Nacional de Pesquisa de Solos, Embrapa-SPI, Rio de Janeiro.

Embrapa (Empresa Brasileira de Pesquisa Agropecuária). 2006. Sistema Brasileiro de Classificação de Solos, Embrapa-SPI, Rio de Janeiro.

Ferreira, T.O. 2002. Solos de mangue do Rio Crumahú (Guarujá-SP): Pedologia e contaminação por esgoto doméstico. Dissertação de Mestrado, Escola Superior de Agricultura “Luiz de Queiroz", Universidade de São Paulo, Piracicaba.

Fitter, A.H. 1987. An architectural approach to the comparative ecology of plant root systems. New Phytologist 106: 61-77.

Huxham, M., Langat, J., Tamooh, F., Kennedy, H., Mencuccini, M., Skov, M.W. \& Kairo, J. 2010. Decomposition of mangrove roots: effects of location, nutrients, species identity and mix in a Kenyan forest. Estuarine, Coastal and Shelf Science 88: 135-142.

Komiyama, A., Ong, J.E. \& Poungpam, S. 2008. Allometry, biomass, and productivity of mangrove forests: A review. Aquatic Botany 89: 128-137.

Kummerow, J., Castillanos, J., Maas, M. \& Larigauderie, A. 1990. Production of fine roots and the seasonality of their growth in a Mexican deciduous dry forest. Vegetation 90: 73-80.

La Scala Júnior, N., De Figueiredo, E.B. \& Panosso, A.R. 2012. A review on soil carbon accumulation due to the management change of major Brazilian agricultural activities. Brazilian Journal of Biology 72: 775-785.

Luchese, E.B., Favero, L.O.B. \& Lenzi, E. 2001. Fundamentos da química do solo. Freitas Bastos Editora, Rio de Janeiro.

Madi, A.P.L.M., Boeger, M.R.T., Larcher, L., Pelozo, A., Sereneski, C., Reissmann, C.B. \& Padial, A.A. 2016. Estrutura do componente de regeneração natural e arbóreo de dois manguezais no estado do Paraná. Ciência Florestal 26: 159-170.

Marques, R. 2006. Caracterização química da fertilidade do solo. In: M.R. Lima (ed.). Diagnóstico e recomendações de manejo de solo: aspectos teóricos e metodológicos. Projeto Solo-Planta. Universidade Federal do Paraná, Curitiba. 
McKee, K.L. 2011. Biophysical controls on accretion and elevation change in Caribbean mangrove ecosystems. Estuarine, Coastal and Shelf Science 91: 475-483.

Menezes, G.V. 2000. Recuperação de manguezais: um estudo de caso na Baixada Santista, Estado de São Paulo, Brasil. Tese de Doutorado. Instituto Oceanográfico, Universidade de São Paulo, São Paulo.

Novais, R.F., Smyth, T.J., Nunes, F.N. 2007. Fósforo. In: R.F. Novais, V.V.H. Alvarez, N.F. Barros, R.L.F. Fontes, R.B. Cantarutti, \& J.C.L. Neves (eds.). Fertilidade do solo. Sociedade Brasileira de Ciência do Solo, Viçosa, pp. $471-550$.

Novais, R.F., Alvarez, V.V.H., Barros, N.F., Fontes, R.L.F., Cantarutti, R.B. \& Neves, J.C.L. 2007. Fertilidade do solo. Sociedade Brasileira de Ciência do Solo, Viçosa.

Prada-Gamero, R.M., Vidal-Torrado, P. \& Ferreira, T.O. 2004. Mineralogia e físico-química dos solos de mangue do Rio Iriri no Canal de Bertioga (Santos, SP). Revista Brasileira de Ciência do Solo 28: 233-243.

Prasad, M.B.K. \& Ramanathan, A.L. 2009. Characterization of phosphorus fractions in the sediments of a tropical intertidal mangrove ecosystem. Wetlands Ecology and Management 18: 272 165-175.
Reef, R., Feller, I.C. \& Lovelock, C.E. 2010. Nutrition of mangroves. Tree Physiology 30: 1148-1160.

Rosado, B.H.P., Martins, A.C., Colomeu, T.C., Oliveira, R.S., Joly, C.A., \& Aidar, M.P.M. 2011. Fine root biomass and root length density in a lowlandand a montane tropical rainforest, SP, Brazil. Biota Neotropica 11: 203-209.

Rossi, M. \& Mattos, I.F.A. 2002. Solos de mangue do Estado de São Paulo: caracterização química e física. Revista do Departamento de Geografia 15:101-113.

SBCS - Sociedade Brasileira de Ciência do Solo. 2004. Comissão de Química e Fertilidade do Solo. Manual de adubação e de calagem para os estados de RS e SC. DBCS, Porto Alegre.

Sessegolo, G.C.S. 1997. Estrutura e produção de serapilheira do manguezal do Rio Baguaçu, Baía de Paranaguá-PR. Dissertação de Mestrado, Universidade Federal do Paraná, Curitiba.

Silvério, P.F. 2003. Bases técnico-científicas para a derivação de valores-guias de qualidade de sedimentos para metais: experimentos de campo e laboratório. Tese de Doutorado, Universidade de São Carlos, São Paulo.

Tomlinson, P.B. 1986. The botany of mangroves. Cambridge University Press, Cambridge. 